\title{
Pengembangan Religiusitas melalui Metode Kisah Qur'ani di Taman Kanak-Kanak
}

\author{
Sri Wahyuni ${ }^{\bowtie 1}$, Sigit Purnama ${ }^{2}$ \\ Pendidikan Islam Anak Usia Dini, Universitas Islam Negeri Sunan Kalijaga, Yogyakarta \\ DOI: $10.31004 /$ obsesi.v5i1.523
}

\begin{abstract}
Abstrak
Penelitian ini bertujuan untuk mendeskripsikan temuan mengenai pengembangan karakter religiusitas pada anak usia dini di Taman Kanak-Kanak (TK) ABA Sapen Yogyakarta. Subjek penelitian ini adalah anak kelas B1 yang berusia 5-6. Penelitian ini menggunakan pendekatan kualitatif dengan metode studi kasus. Sumber data diperoleh dari kepala sekolah, guru kelas, guru pendamping dan orang tua murid. Data diperoleh dari hasil observasi, wawancara, dan dokumentasi. Strategi validitas atau keabsahan data yang digunakan adalah dengan mentringulasi data. Analisis data terdiri dari beberapa tahapan mengolah dan mempersiapkan data, membaca keseluruhan data, menganalisis lebih dengan mengkoding data, menerapkan proses koding, pendeskripsian, memaknai data. Hasil penelitian menunjukkan tahapan pelaksanaan, 1) tahap perencanaan, 2) penerapan, 3) evaluasi. Implikasi dari penerapan metode kisah Qur'ani telah memberi pengaruh pada karakter religiusitas anak. Nilai-nilai dari karakter tersebut adalah mengenal agama yang dianut, mengerjakan ibadah, berperilaku jujur, penolong, hormat, sportif, menjaga kebersihan diri dan lingkungan, mengetahui hari besar agama, menghormati (toleransi).

Kata Kunci: religiusitas; anak; metode kisah Qur'ani.
\end{abstract}

\begin{abstract}
This study aims to describe the findings regarding the development of the character of religiosity in early childhood in Taman Kanak-Kanak (TK) ABA Sapen Yogyakarta. The subjects of this study were B1 graders aged 5-6. This research uses a qualitative approach with a case study method. Data sources were obtained from the school principal, class teacher, teacher assistant and parents of students. Data obtained from the results of observations, interviews, and documentation. The validity or validity of the data strategy used is by tinging the data. Data analysis consists of several stages of processing and preparing data, reading the entire data, analyzing more by coding data, implementing the coding process, describing, interpreting data. The results showed the stages of implementation, 1) the planning stage, 2) implementation, 3) evaluation. The implication of applying the Qur'anic story method has an influence on the character of children's religiosity. The values of these characters are to know the religion that is adopted, do worship, behave honestly, help, respectful, sportsmanship, maintain personal hygiene and the environment, know the religious holidays, respect (tolerance).
\end{abstract}

Keywords: religiosity; children; the Qur'anic story method.

Copyright (c) 2019 Sri Wahyuni dan Sigit Purnama

$\triangle$ Corresponding author :

Email Address : sri.wahyuni02feb@gmail.com ( Yogyakarta, Indonesia )

Received 20 April 2020, Accepted 8 May 2020, Published 11 may 2020 


\section{PENDAHULUAN}

Anak usia dini ialah anak yang berumur 0-6 tahun yang memiliki pertumbuhan dan perkembangan yang lebih pesat dan fundamental pada awal-awal tahun kehidupannya. Perkembangan anak merupakan suatu proses ke arah yang lebih sempurna dan tidak begitu saja dapat diulang kembali. Oleh karena itu, kualitas perkembangan anak pada masa depannya sangat ditentukan oleh stimulasi yang diperolehnya sejak dini. Pemberian stimulasi pendidikan adalah hal yang sangat penting, bentuk stimulasi yang diberikan haruslah dengan cara yang tepat sesuai dengan tingkat perkembangannya (Khadijah, 2017).

Menurut Ikhwan al-Shafa mengakui bahwa semua ilmu dan sastra yang tidak mengantarkan pemiliknya menuju concern terhadap akhirat, dan tidak memberikan makna hanya akan menjadi bumerang baginya (Ridla, 2002, p. 77-78). Bayangkan saja bagaimana jika generasi penerus di didik dan menjadi ahli di berbagai bidang keilmuan tetapi tidak ada nilai-nilai pendidikan Islam dalam dirinya, maka keahlian tersebut akan digunakan dengan semaunya dan dapat membawa kerusakan di bumi Allah SWT.

Hendaknya pengajaran keruhanian dan akhlak dalam konteks ini mestilah tak berhenti pada sekedar rutinitas peribadahan dan pengajaran akhlak yang bersifat kognitif belaka, melainkan disadarkan pada pemahaman makna batiniah dari ajaran-ajaran agama dan akhlak. Berapa banyak orang yang ingin berbuat baik, tetapi sulit dijadikan kenyataan. Penggarapan ranah psikomotorik terkait pengembangan etos kejujuran, kerja keras, profesionalisme, kesopanan, dan filantropis-sosial dalam bentuk pengembangan disiplin dan latihan yang nyata (disebut riyadhah atau mujahadah dalam tasawuf atau sufisme) dan bukan semata-mata secara intelektual-akademis dan emosional (Bagir, 2019, p. 177).

Usia dini merupakan saat yang tepat untuk meletakkan dasar-dasar dari aspek perkembangan anak, salah satu aspek perkembangan yang harus dikembangkan dalam diri anak adalah aspek nilai agama dan moral. Mengajarkan agama pada anak memiliki tujuan mulia, yaitu membentuk pribadi anak yang shalih dan shalihah, mendekatkan diri kepada Allah dalam rangka menggapai ridha-Nya dan memiliki keimanan kuat. Hanya orang-orang yang memiliki keimanan kuat yang akan mampu bertahan menghadapi beratnya berbagai tantangan kehidupan (Masdalipah, 2017, p. 2).

Karakter merupakan nilai-nilai perilaku dari manusia yang berhubungan dengan Tuhan yang Maha Esa, diri sendiri, sesama makhluk ciptaan manusia (manusia, hewan, tumbuhan), dan nilai kebangsaan yang terwujud dalam pikiran, sikap, perasaan, perkataan serta perbuatan berdasarkan norma-norma agama, hukum, tata krama, budaya, dan adat istiadat. Pendidikan karakter merupakan suatu sistem yang berfungsi untuk menanamkan nilai-nilai karakter kepada seluruh warga sekolah yang meliputi komponen pengetahuan, kesadaran dan kemauan, serta tindakan untuk melaksanakan nilai-nilai tersebut (Muslich, 2011, p. 84).

Pendidikan karakter sangat cocok jika diimplementasikan pada anak dari sejak dini ketika anak masih berada di taman kanak-kanak. Pendidikan merupakan salah satu cara membentuk karakter anak pada usia dini. Sedangkan sekolah merupakan wadah untuk mensukseskan kegiatan pembelajaran yang bertujuan untuk pembentukan karakter anak (Trimuliana, Dhieni, \& Hapidin, 2019, p. 570). Oleh karena itu, dalam melakukan proses pembelajaran di PAUD pendidik dapat menggunakan berbagai media dan kegiatan yang dapat digunakan ketika pembelajaran berlangsung, penggunaan media dan pelaksaan kegiatan pembelajaran yang diberikan kepada anak di dalamnya terdapat pendidikan karakter.

Namun pada kenyataannya, pendidikan Islam sepertinya belum memainkan peran strategisnya dalam menciptakan pribadi-pribadi muslim yang unggul dan berkepribadian baik Masih banyaknya praktik di lembaga-lembaga pendidikan agama yang masih memberikan dominasi pada aspek kognitif dan penekanan pada aspek hafalan dalam memahami pendidikan keagamaan, hal ini dapat dilihat dari penilaian yang diterima anak 
yang menjadi penentu kualitas lulusan dari sebuah lembaga pendidikan. Kepribadian dan akhlak anak didik hanya berhenti pada nilai angka-angka nominal semata, keberhasilan pendidikan agama diukur manakala anak memperoleh angka di atas KKM, kepintaran anak dinilai manakala mampu menghafal materi-materi agama yang sudah ditentukan berdasarkan bahan ajar yang ada dan batasan-batasan yang sudah dipersiapkan secara terukur dan terstruktur menurut aturan yang sangat sempit dan sangat minim terhadap ruang dialog-interaktif antar guru dan peserta didik (Rohinah, 2018, p. 2).

Mengembangkan karakter religius sejak dini adalah salah satu cara agar anak dapat melakukan ibadah secara sadar dan ikhlas kepada Tuhan yang Maha Esa. Ibadah adalah taat kepada Allah dengan melaksanakan perintah-Nya melalui lisan para Rasul-Nya, ibadah adalah merendahkan diri kepada Allah Azza wa Jalla yaitu tingkatan tunduk yang paling tinggi disertai dengan rasa mahabbah (kecintaan) yang paling tinggi (Rokim, 2015, p. hlm. 776).

Kisah Islami lebih banyak menyoroti penggunaan kisah-kisah Isra'iliyat dalam memahami Al-Qur'an (Suyanta, 2013, p. 11). Al-Qur'an memiliki banyak kisah-kisah, meskipun bukan dogeng. Kisah-kisah teladan tersebut kalau diceritakan guru kepada anakanak dengan bahasa yang mudah dan sederhana akan selalu disukai anak-anak. Pada usia dini, perhatian anak lebih tertuju pada cara guru menceritakan agama dari pada isi ajarannya dan cerita akan lebih menarik jika berhubungan dengan masa anak-anak karena sesuai dengan jiwa kekanak-kanakannya. Dengan caranya sendiri anak mengungkapkan pandangan teologisnya, pernyataan dan ungkapannya tentang Tuhan lebih bernada individual, emosional, dan spontan tapi penuh arti teologis (Sit, 2016, p. 23). Pengembangan karakter religiusitas pada anak-anak taman kanak-kanak harus menggunakan metodemetode yang kreatif dan menyenangkan agar tujuan proses pembelajaran tercapai dengan baik.

Penelitian ini didasarkan pada penelitian terdahulu oleh (Dwi, 2017), dengan fokus utama menanamkan nilai karakter religius pada siswa berbasis kepada Al-Qur'an dan sunnah sebagai pedoman hidup umat muslim, bagaimana pembiasaan-pembiasaan dilakukan di sekolah dan meminta anak untuk mempraktikkan pembiasaan tersebut. Kendala yang dihadapi adalah anak hanya melakukan pembiasaan tersebut jika sedang berada di depan guru, tidak menjamin anak akan melakukan hal yang sama ketika berada di luar pengawasan guru. Artikel yang di tulis Masganti Sitorus (Sit, 2016) memamparkan secara teoritik sifat beragama anak usia dini, mengungkapkan bahwa sikap beragama anak yang suka meniru dan tertarik dengan kisah-kisah yang berkaitan dengan kehebatan tokohtokoh yang diceritakan, dan belum ada penggalian secara praktis bagaimana penerapan cerita yang tepat untuk anak. Secara umum artikel (Dalimunthe, 2016) mengungkapkan keunggulan dari kisah-kisah yang terdapat dalam Al-Qur'an, kisah-kisah ini dapat diberikan dari berbagai tingkatan TK-SMA bahkan untuk umum asalkan disampaikan oleh orang yang ahli. Penelitian ini melengkapi penelitian sebelumnya dengan melihat langsung bagaimana pelaksaan metode kisah Qur'ani di PAUD. Penelitian ini bertujuan untuk mencari tahu bagaimana proses pelaksanaan kegiatan metode kisah Qur'ani dan melihat implikasinya terhadap perkembangan karakter religiusitas anak melalui metode kisah Qur'ani.

\section{METODOLOGI}

Penelitian ini termasuk penelitian lapangan (field research), peneliti terjun langsung ke lokasi penelitian dengan mengambil gambar latar belakang TK Aisyiyah Bustanul Athfal Sapen Yogyakarta. Metode penelitian ini menggunakan pendekatan kualitatif dengan strategi studi kasus. Partisipan penelitian adalah orang-orang yang menjadi sumber dalam penelitian dan dapat memberikan informasi terkait dengan penelitian yang akan di laksanakan, yakni guru kelas, guru pendamping, perwakilan wali murid dari kelas B1, dan kepala sekolah TK ABA Sapen Yogyakarta. 
Pendekatan ini secara teknis memiliki langkah-langkah prosedural yang dijelaskan oleh Creswell pada gambar bagan serta uraian di bawah ini;

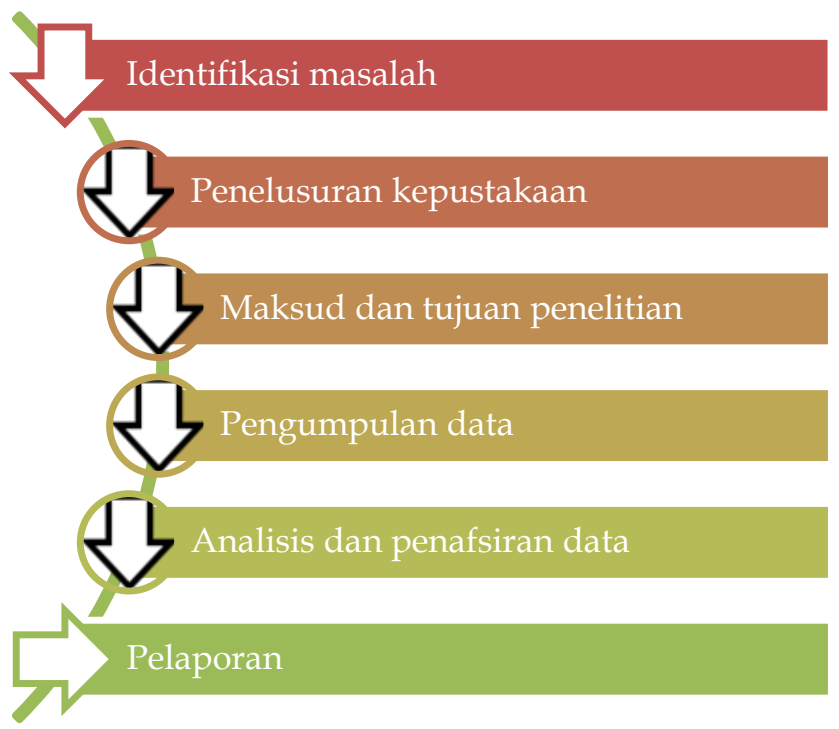

Bagan 1. Langkah-langkah Prosedural penelitian kualitatif (Creswell, 2010)

Penelitian dilakukan di TK ABA Sapen Yogyakarta, pada semester III (Ganjil) Tahun Ajaran 2018-2019. Teknik pengumpulan data berupa pengamatan, wawancara, dan dokumentasi. Pengamatan dilakukan dengan bantuan alat tulis dan kamera untuk mencatat dan merekam kegiatan yang sedang berlangsung, wawancara yang digunakan adalah jenis wawancara semi terstruktur yang dibuat berdasarkan indikator perkembangan nilai agama dan moral anak usia 5-6 tahun.

Analisis data dilakukan dengan cara mengolah dan mempersiapkan data, membaca keseluruhan data, menganalisis lebih detail dengan mengkoding data, menerapkan proses koding, pendeskripsian, menginterpretasi atau memaknai data. Pada akhir kegiatan penelitian, hasil analisis atau interpretasi data digunakan untuk menarik kesimpulan dalam penelitian (Creswell, 2010, pp. 275-277). Strategi validitas atau keabsahan data yang digunakan adalah dengan triangulasi (triangulate) data yang ada (Creswell, 2015, pp. 139141). Teknik triangulasi dalam pengambilan data dengan wawancara menggunakan triangulasi teknik dan triangulasi sumber, proses ini dilakukan guna menghasilkan informasi yang memiliki tingkat kredibilitas yang tinggi dan dapat menggambarkan informasi yang sesungguhnya terjadi di dalam ruang interaksi. Triangulasi teknik terdiri dari observasi, wawancara, dan dokumentasi.

Proses yang dilakukan peneliti adalah dengan mendatangi tempat penelitian, mengamati objek penelitian, dan berada di dalam ruang interaksi untuk mengetahui aktivitas yang dilakukan oleh sekolah dalam pengembangan religiusitas pada anak usia dini melalui metode kisah Qur'ani.

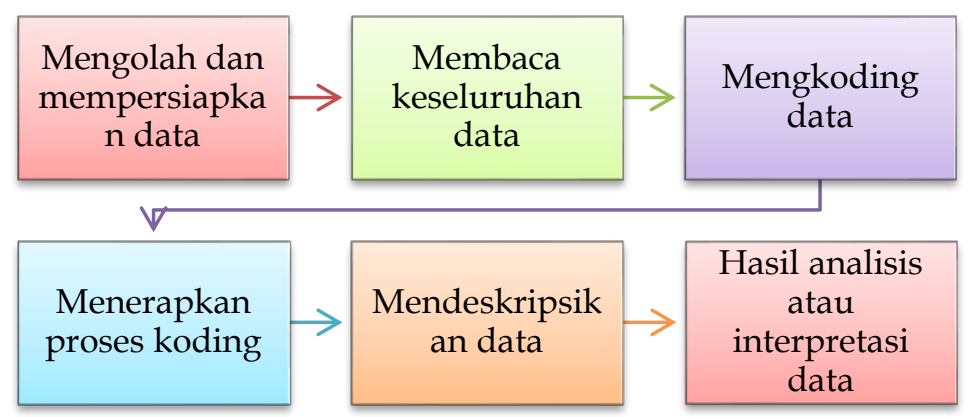

Bagan 2. Tahapan analisis data penelitian kualitatif (Creswell, 2010, p. 277) 


\section{HASIL DAN PEMBAHASAN}

Sebelum memutuskan untuk melakukan penelitian ini, peneliti terlebih dahulu melakukan observasi awal, informasi diperoleh dengan melanjutkan teknik pengamatan yaitu mewawancarai para informan guna menghasilkan informasi yang mampu menjawab permasalahan dalam penelitian ini, dilanjutkan dengan melakukan dokumentasi untuk memperkuat informasi dari hasil wawancara ataupun dari pengamatan yang dilakukan oleh peneliti selama penelitian berlangsung dari awal hingga di akhir penelitian. selanjutnya dilakukan triangulasi sumber dengan cara cross check data dengan fakta dari informan yang berbeda-beda dan hasil penelitian lainnya.

Pada prinsipnya pembelajaran yang dilaksanakan di TK ABA Sapen Yogyakarta berlatar belakang nilai-nilai Islami, TK ABA Sapen menggunakan model pembelajaran area, di mana di setiap area akan memiliki tujuan perkembangan yang berbeda pula. TK ini juga menggunakan pembelajaran berbasis islami dan kontekstual. Seperti kita ketahui bahwa anak-anak usia dini memiliki rasa ingin tahu yang sangat besar (strong desire to investigate things) dan memorinya terus bertambah (Britton, 1992, p. 32). Pada prinsipnya, sekolah Islam terpadu merupakan perubahan atas kegagalan yang dilakukan sekolah umum dan lembaga pendidikan Islam, untuk memadukan ilmu umum dan agama. Sehingga, dalam praktiknya, sekolah Islam terpadu melakukan pengembangan kurikulum dengan cara memadukan kurikulum pendidikan umum yang ada di Kementerian Pendidikan Nasional (Yasyakur, 2017, p. 83). Tujuan pendidikan Islam harus selaras dengan tujuan di ciptakannya manusia oleh Allah SWT, yaitu menjadi hamba Allah SWT yang dengan kepribadian muttaqin (Zein, 2018, p. 305).

Kisah-kisah yang diperdengarkan kepada anak-anak di Indonesia masih sedikit yang mengandung unsur $\mathrm{n}-A$ ch sebagaimana dikemukakan atau cerita yang mengandung motivasi (Manney, 2008, p. 51). Penting untuk memilih kisah yang tepat mengingat anak usia dini sangat haus akan pengetahuan baru, anak seolah-olah mampu menyerap segala hal dalam waktu cepat, maka dari itu hal ini harus dapat dimanfaatkan sebaik mungkin oleh pendidik untuk mengenalkan hal-hal baru kepada anak sesuai dengan tingkatan usia anak. Kegiatan rutin dalam mengembangkan karakter religiusitas pada anak di sekolah adalah membiasakan anak mengucapkan dan menjawab salam, membiasakan anak berdoa sebelum dan sesudah melakukan kegiatan, mengajarkan anak membaca dan menghafal ayat-ayat AlQur'an, mengajarkan anak kegiatan-kegiatan beribadah (sholat dhuha berjamaah), membiasakan anak mengucapkan maaf dan terimakasih, membacakan kisah-kisah yang ada dalam Al-Qur'an yang diharapkan mampu menjadi teladan dari nilai-nilai yang terkandung di dalamnya.

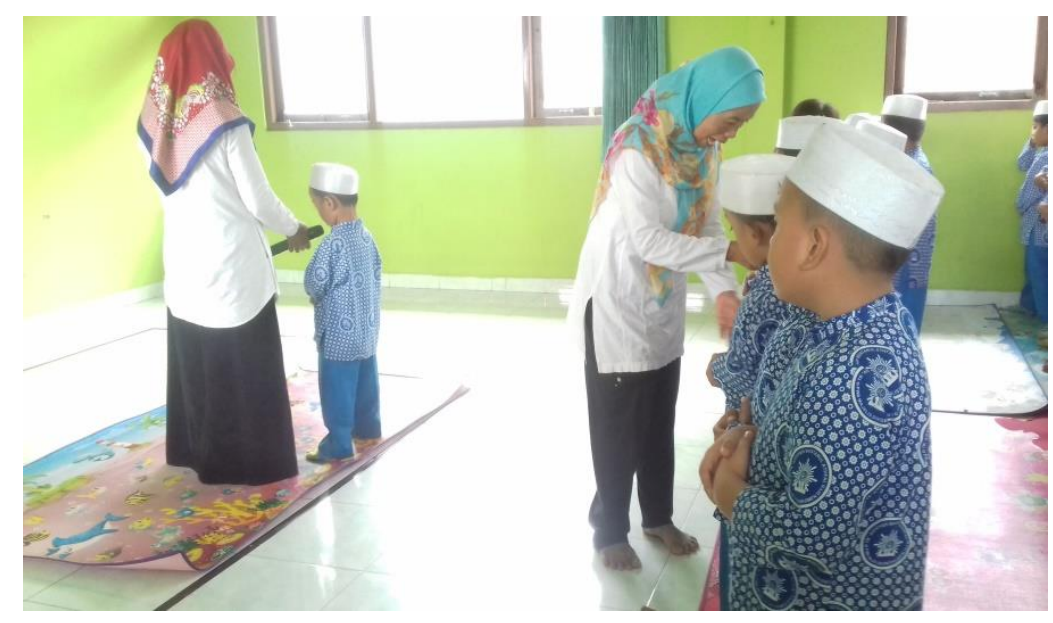

Gambar 1. Shalat Dhuha Berjama'ah

Sumber: Dokumentasi kegiatan beribadah (2020) 
Gambar 1. memperlihatkan anak-anak yang sedang melaksanakan kegiatan ibadah berupa sholat dhuha berjamaah. Guru membimbing dan mengawasi anak dari awal sampai kegiatan selesai, sholat dhuha berjamaah merupakan salah satu kegiatan rutin yang dilakukan sekolah setiap hari rabu, anak laki-laki secara bergantian mendapatkan kesempatan untuk berdiri di depan menjadi imam. Dengan adanya kegiatan ini anak akan terbiasa untuk mengulang bacaan sholat, anak akan terbiasa untuk melaksanakn sholat berjamaah, dan yang menjadi harapan besar dari kegiatan ini adalah anak terbiasa untuk melaksanakan ibadah kepada Allah Swt dengan perasaan ikhlas.

Perkembangan berbicara anak pada usia golden age berlangsung dengan sangat cepat seperti terlihat dalam perkembangan pengertian dan keterampilan berbicara. Pada masa ini anak telah dapat menerima dan memahami perintah dengan cukup baik (Harlock, 2009, p. 140). Perkembangan bahasa yang sangat pesat ini dapat dimanfaatkan oleh pendidik untuk membentuk karakter anak melalui berbagai macam kegiatan yang membutuhkan perkembangan bahasa anak. Perkembangan bahasa anak pada masa ini dapat dilihat pada indikator standar perkembangan anak usia 5-6 tahun yaitu anak dapat berkomunikasi secara lisan, memiliki perbendaharaan kata, serta mengenal simbol-simbol untuk persiapan membaca, menulis, dan berhitung (Hasan, 2010). Indikator tersebut dapat dilihat dari kegiatan sehari-hari yang terlihat di lapangan seperti menyapa dengan sapaan yang sopan lagi santun (anak-anak menggunakan bahasa Jawa misalnya kula nuwun, nuwun sewu, dll), telah mampu membaca dan bahkan menghafal ayat-ayat pendek Al-Qur'an, mampu memahami cerita yang disampaikan oleh guru, mampu memahami kalimat perintah, anak mampu memahami penulisan huruf dan angka arab.

Kegiatan pembelajaran yang berlangsung di TK ABA Sapen Yogyakarta dibagi menjadi tiga kegiatan pokok, yakni kegiatan pembuka, kegiatan inti, dan kegiatan penutup. Biasanya guru-guru melaksanakan kegiatan menceritakan kisah-kisah pada kegiatan awal, ini dikarenakan fokus anak belum terpecah. Di jelaskan oleh kepala sekolah TK ABA Sapen bahwa kegiatan menceritakan kisah-kisah Al-Qur'an dilakukan di awal karena waktu-waktu tersebutlah biasanya anak dalam kondisi siap menerima pelajaran, sehingga para guru lebih memilih untuk melakukan kegiatan ini di awal pembelajaran.

Melalui wawancara yang dilakukan, kepala sekolah mengungkapkan "Kami dari pihak sekolah mewajibkan semua guru untuk membuat perencanaan pembelajaran sendiri. Tujuan dari ketentuan ini diharapkan agar setiap kegiatan yang dilakukan oleh guru dapat berjalan terarah dan sesuai dengan rencana yang telah dibuat sebelumnya, guru pun akan lebih siap dalam mengajar jika telah ada panduan yang telah dibuat". Menurut (Eriani, 2019, p. 304) berhasilnya metode cerita/kisah terlihat ketika anak dapat duduk dengan rapi, antusias, mendengarkan dan memperhatikan cerita dari awal sampai akhir, dapat menyebutkan berbagai tokoh dan sifatnya, serta dapat menceritakan kembali dengan bahasa anak sendiri. Fakta di lapangan, pelaksanaan kegiatan bercerita yang dilakukan oleh guru disambut antusias oleh anak-anak. Sebelum mulai bercerita, guru mengatur tempat duduk terlebih dahulu, guru meminta anak-anak untuk duduk dengan pola melingkar. Setelah anak-anak telah duduk dengan rapi dan terkondisikan dengan baik, kemudian guru membuat kesepakatan dengan anak agar anak tetap tenang dan menyimak sehingga nilainilai yang ingin disampaikan oleh guru dapat diterima anak dengan baik. Setelah guru dapat mengambil perhatian anak barulah guru memulai cerita.

Bahasa yang digunakan oleh para guru dalam menyampaikan kisah-kisah begitu sederhana, ini dimaksudkan agar anak mampu menyaring informasi dengan baik dan anak dapat memperoleh pemahaman terhadap kisah yang diceritakan guru. Dari hasil observasi terlihat bahwa guru mampu membuat anak-anak terbuai dengan cerita kisah yang sedang mereka dengarkan, anak-anak menunjukkan ekspresi kagum, senang, tertawa, dan antusias setiap kata-kata yang keluar dari mulut gurunya. Guru menirukan suara tokoh-tokoh yang berperan dalam kisah tersebut, seperti yang dilakukan oleh guru kelas B1 ketika menirukan suara yang berat untuk satu tokoh dan suara yang lebih ringan untuk tokoh yang lain, ini 
dapat menarik perhatian anak sekaligus membuat anak lebih memahami dialog dalam kisah tersebut. Kisah atau cerita (storytelling) yang religius, inspiratif dan motivasional dapat mengembangkan etos kerja keras dan menumbuhkan spiritualitas sehingga berimplikasi pada kemajuan sebuah Bangsa (Suyadi, 2018, p. 53).

Guru dan murid secara bersama-sama membuat kesimpulan dari kisah yang telah di sampaikan, dikarenakan Kisah dalam al-Quran adalah media yang dibingkai hanya untuk menyampaikan pesan-pesan tauhid, kebaikan, dampak perilaku buruk, kebenaran, dan moral yang bermutu (Affani, Pamekasan, Raya, \& Km, 2017, p. 195). Lanjutkan dengan melakukan evaluasi terhadap peserta didik (Syahraini, 2014, p. hlm. 184.). Setelah guru selesaikan menceritakan kisah tersebut, guru tidak lupa mengajukan tanya jawab dengan anak-anak tentang siapa saja tokoh yang ada dalam kisah nabi Musa As, bagaimana sifatsifat dari tokoh yang dikisahkan tadi, dan bagaimana tanggapan anak-anak dengan sifat toko-tokoh dalam kisah Nabi Musa As. Dari hasil pengamatan yang dilakukan peneliti, terlihat bahwa secara keseluruhan anak aktif dalam bertanya dan menjawab dengan sesuai dari pertanyaan guru secara bergiliran. Di akhir, guru menyampaikan isi pesan moral yang terkandung dalam kisah yang telah disampaikan.

Selama kegiatan berkisah berlangsung terlihat jelas anak-anak terpesona dengan kisah yang disampaikan guru. dengan penuh penghayatan. Anak-anak seperti terhipnotis dengan kisah yang mereka dengar sehingga emosi dari anak-anak juga ikut terbawa dalam alur kisah yang sedang dibawakan oleh guru.

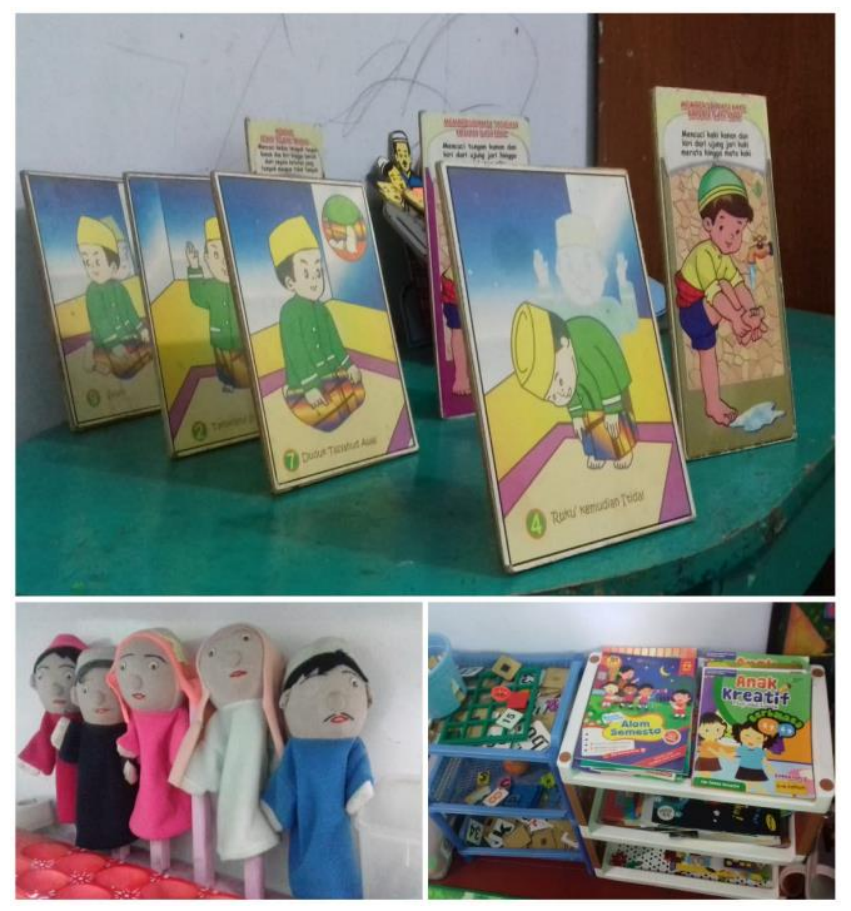

Gambar 2. Media Metode Kisah Qur'ani

Sumber: Dokumentasi kegiatan berkisah (2020)

Gambar 2. Memperlihatkan beberapa media yang paling sering digunakan guru ketika menggunakan metode kisah Qur'ani, media tersebut berupa boneka tangan, buku cerita islami, dan miniatur gambar. Dengan media, kisah yang diceritakan guru akan menjadi lebih menarik, guru akan lebih mudah menarik perhatian anak, dengan demikian, pesan yang ingin disampaikan guru kepada anak akan lebih mudah tersalurkan.

Pada minggu selanjutnya, guru kembali menggunakan kisah Qur'ani. Tentu dengan pemilihan judul yang berbeda dengan minggu sebelumnya. Dengan demikian diharapkan semakin banyak ragam kisah Al-Qur'an yang diceritakan dan semakin banyak pulan pesanpesan moral yang dapat diterima oleh anak. Setiap kisah memiliki nila-nilai pembelajaran 
yang berbeda, tepat rasanya jika variasi dalam berkisah dilakukan guru. Kegiatan berkisah yang dilakukan pada minggu selanjutnya berjudul "Kisah si Qarun" yang disampaikan oleh Ibu SH. pada kegiatan berkisah di minggu ini, guru menggunakan buku cerita kisah-kisah Al-Qur'an. Tetapi bahasa yang digunakan lebih disederhanakan sehingga anak lebih mudah dalam menyerap pesan-pesan moral yang terdapat dalam kisah.

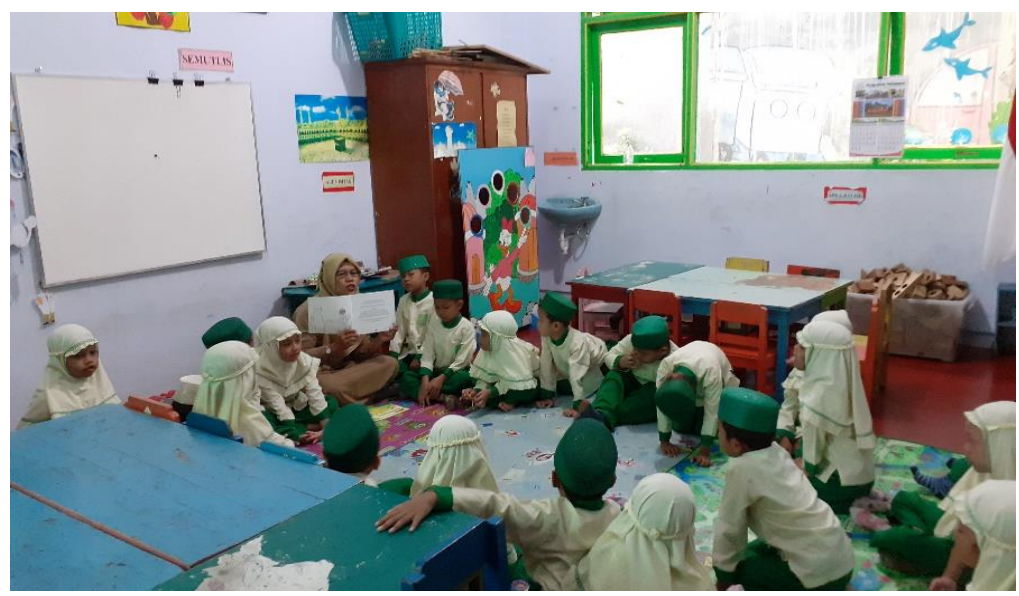

Gambar 3. Berkisah Menggunakan Media Buku Bergambar Sumber: Dokumentasi kegiatan berkisah (2020)

Gambar 3. Menunjukkan bagaimana kondisi saat proses pelaksaan kegiatan berkisah sedang berlangsung, gambar di atas memperlihatkan guru menggunakan media buku cerita bergambar islami untuk menarik perhatian anak, anak terlihat duduk melingkar dan antusias mendengarkan kisah yang diceritakan oleh guru.

Dari hasil pengamatan selama kegiatan berkisah yang dilakukan di kelas B1, dapat dilihat bahwa anak-anak terlihat terbawa dalam kisah yang sedang didengar dari guru, hal ini dapat dilihat dari dari ekspresi yang ditunjukkan anak yang begitu serius mengikuti setiap gerakan-gerakan yang diperagakan oleh gurunya. Selama kegiatan berkisah berlangsung, guru tidak menggunakan alat peraga, hanya alat bantu berupa miniaturminiatur untuk menarik fokus anak, selebihnya guru menggunakan ekspresi yang tepat untuk mewakili cerita karakter dan alur kisah yang sedang disampaikan. Di sini guru mengandalkan kemampuan bahasa dan ekspresi yang menarik, guru dapat mengekspresikan perasaan sedih, senang, takut, marah, cemburu, dan lainnya. Bahasa yang digunakan guru bernada tinggi, sedang, dan rendah sesuai dengan keadaan dalam kisah tersebut, contohnya ketika ada seseorang yang sedang meminta tolong, guru akan meninggikan suaranya dengan ekspresi takut untuk menggambarkan suasana yang mencekam dalam kisah. Walaupun guru tidak menggunakan alat peraga tetapi kegiatan berjalan dengan baik dan kondusif, seperti yang dikatakan oleh (Dalimunthe, 2016, p. hlm. 276.) metode kisah menjadi menarik jika disampaikan oleh orang profesional. Menurut (Aziz, 2018, p. 52) Metode kisah harus disesuaikan dengan tingkat perkembangan peserta didik. Selain itu materi kisah seharusnya mengandung pelajaran bagi kehidupan setelah sesi kisah berakhir, guru mengulang kembali point-point penting untuk dibahas kembali bersama anak, ini dilakukan agar nilai-nilai yang ingin disampaikan kepada anak dapat diterima anak dengan baik. Hal ini dilakukan dengan memberikan pertanyaan kepada anak seputar kisah tadi dan anak diminta untuk menanggapinya.

Metode kisah Qur'ani yang dilakukan oleh guru tidak terlepas dari evaluasi. Evaluasi dilakukan dengan tujuan untuk memperbaiki metode-metode yang digunakan dalam pembelajaran dapat lebih baik lagi kedepannya. Menurut (Sudjana, 2017, p. 25) Evaluasi merupakan penilaian guru terhadap proses pembelajaran yang telah dan sedang berlangsung. Dengan melakukan evaluasi, guru akan tahu sejauh mana tujuan pembelajaran 
yang telah dibuat sebelumnya apakah sudah tercapai, dan dapat melihat hambatanhambatan yang ada selama pembelajaran berlangsung. Evaluasi yang dilakukan guru berupa lisan dan tulisan. Evaluasi lisan yang dilakukan guru di TK ABA Sapen Yogyakarta adalah dengan cara menanyakan kepada anak isi kisah yang diceritakan. Guru melakukan percakapan ringan dengan anak, ini dilakukan untuk memberikan persepsi terhadap aspekaspek perkembangan anak, seperti bahasa, nilai agama dan moral, dll. Evaluasi yang dilakukan guru adalah dengan cara observasi (pengamatan) secara langsung bagaimana tingkah laku anak sehari-hari ketika berada di sekolah.

Metode kisah Qur'ani sangat efektif untuk diterapkan pada anak usia dini, cara ini memiliki pengaruh yang bersifat psikologis, kesan yang membekas di dalam benak dan argumentasi rasional (Kurniasih, 2010, p. 127). Metode kisah Qur'ani merupakan salah satu metode yang sangat diminati oleh anak-anak di TK ABA Sapen Yogyakarta. Hal ini dapat dilihat dari antusiasme anak, serta ekspresi yang ditunjukkan anak ketika kegiatan sedang berlangsung. Ekspresi-ekspresi anak ketika mendengarkan kisah antara lain senang, anakanak tertawa, anak-anak terlihat gembira ketika guru menerapkan metode kisah Qur'ani dengan cara mengubah-ngubah bunyi suara sesuai dengan tokoh yang sedang dikisahkan, ditambah lagi dengan persiapan yang dilakukan guru agar penyampaian yang dikemas dengan penuh kesan dapat diterima dengan baik oleh anak. Sehingga kisah-kisah yang disampaikan guru penuh dengan pesan-pesan dan itu tersirat dalam diri anak.

Dari hasil wawancara dengan wali murid mengungkapkan "Kami sebagai orang tua sadar sangat penting menanamkan nilai-nilai pendidikan karakter religius kepada anak sedini mungkin, mengingat banyaknya kasus pelecehan seksual terhadap anak, maka sejak dini anak harus diberikan pendidikan karakter, agar saat dewasa mereka dapat mempertimbangkan baik dan buruknya sesuatu sesuai dengan ajaran agama yang dianutnya sebelum mereka melakukan hal tersebut. Perkembangan karakter anak akan berpengaruh dengan kegiatan sehari-hari yang dia lakukan". Kegiatan berkisah dapat mengoptimalkan perkembangan nilai agama dan moral anak, ini merupakan nilai-nilai untuk menciptakan seorang anak supaya memiliki karakter religius. Apalagi jika kisah itu menyenangkan di dengar oleh anak, anak akan menyimak kisah tersebut dengan baik. Dengan demikian, akan timbul rasa ingin tahu anak, muncul pertanyaan dalam diri anak dan menanyakan kepada gurunya. Motode kisah ini juga dapat mengembangkan perkembangan lain anak, antara lain bahasa, sosial, dan kognitif, dll". Dengan demikian perlu adanya pembelajaran yang kreatif dan inovatif dari guru misalnya dalam memilih atau menentukan strategi pembelajaran, memilih alat atau media, jenis dan bentuk sistem pembelajaran serta alat evaluasi hal ini dilakukan agar kegiatan yang dilaksanakan lebih menarik dan bias membangkitkan rasa ingin tahu anak dan memotivasi anak untuk berfikir kritis dan bisa menentukan hal-hal baru (Pura, 2019, p. 132).

Pentingnya menanamkan pendidikan karakter kepada peserta didik atau generasi muda agar bisa mengontrol moral serta akhlak mereka, sehingga bisa melaksanakan seperti yang di ungkapkan oleh sang proklamator yaitu berdiri diatas kaki sendiri, dalam artian berkarakter atau mempunyai karakter (Cahya, Fajar Septian, Bahri, 2016, p. 93). Akhlak merupakan jiwa agama Islam sehingga diperlukan metode yang tepat dalam membentuk dan membinanya. Al-Qur'an memberikan isyarat bahwa kisah mempunyai peranan penting dalam membentuk dan membina akhlak (Mucharomah, 2017, p. 147). Metode bercerita atau kisah dapat mengubah etika anak-anak karena sebuah kisah mampu menarik anak-anak untuk menyukai dan memperhatikan, serta merekam peristiwa dan imajinasi yang ada dalam kisah (Umayah, 2016, p. 98). Maksud cerita adalah baik (positif), namun disampaikan dengan redaksi negatif. Akibatnya, anak-anak lebih menangkap pesan mental emosional yang sifatnya negatif dari pesan sadar-rasional yang sifatnya positif, begitu pula mengajarkan anak dengan paksaan dapat menghambat perkembangan akademik anak (Nur'aini, 2016, pp. 245-246). Metode kisah Qur'ani yang digunakan di TK ABA Sapen Yogyakarta selalu mengaitkan setiap materi yang akan disajikan dengan nilai-nilai 
pendidikan Islam, sehingga perkembangan nilai agama dan moral anak dapat terstimulasi. Hal ini dapat dilihat ketika kegiatan berkisah sedang berlangsung, guru tidak lupa memasukkan hadis-hadis dan ayat Al-Qur-an yang berkaitan dengan kisah, ini dilakukan untuk menguatkan aqidah dan akhlak anak melalui isi kisah.

Dari pemaparan di atas, dapat disimpulkan ada beberapa hal dan tahapan yang harus dipersiapkan oleh guru dalam berkisah, ini dilakukan supaya mempermudah dalam mengembangkan karakter religius pada anak, antara lain: 1) materi kisah, 2) mengkaji kisah, 3) membuat alur cerita, 4) guru terlebih dahulu membuat rancangan untuk pembuka dan penutup kisah, 5) skill dalam berkisah, 6) media yang digunakan, 7), memilih diksi dan struktur cerita 8) berkisah dengan menggunakan bantuan alat peraga, 9) berkisah tanpa menggunakan media, 10) mengekspresikan karakter dari tokoh yang dikisahkan, 11) membuat bunyi dari suara, 12) menghidupkan suasana, 13) memilih dan mempersiapkan lokasi untuk berkisah, ruangan untuk kegiatan ditata dengan cara yang berbeda sehingga anak nyaman. Penataan ruangan yang baik, berupa meja dan kursi disesuaikan dengan sarana yang diperlukan sehingga anak mempunyai ruang gerak yang leluasa (Zurqoni, 2018, p. 84).

Hasil pengamatan yang dilakukan peneliti di TK ABA Sapen Yogyakarta, sekolah memiliki faktor penunjang dalam pelaksaan kisah Qur'ani untuk mengembangkan karakter religiusitas anak seperti yang telah dijelaskan di atas, namun juga terdapat hambatan yang jadi tugas sekolah untuk mengevaluasi dan lebih baik lagi ke depannya. Menurut (Tanto \& Supena, 2019, pp. 343-344) mengungkapkan penggunaan gadget secara berlebihan, dan menonton televisi tanpa ada pembatasan waktu merupakan bagian dari faktor penghambat. Faktor pendukung dan faktor penghambat dalam penggunaan metode kisah Qur'ani yang ditemukan di lapangan: 1) pendidik, setiap guru telah mendapatkan pelatihan dan pembekalan dalam menggunakan metode ini kisah Qur'ani, 2) Lingkungan, lingkungan sekolah berada di samping mesjid sehingga anak terbiasa melihat kegiatan beribadah orangorang sekitar, 3) sumber belajar, guru masih mudah untuk mendapatkan sumber bacaan, di dalam kelas telah disediakan berbagai jenis macam buku bergambar termasuk buku kisahkisah dalam Al-Qur'an, 4) waktu menjadi hambatan bagi pendidik dalam melaksanakan kegiatan berkisah, dikarenakan banyak hal tak terduga akan terjadi selama jam berkisah berlangsung dan waktu yang kurang. 5) hambatan pengelolaan kelas, Guru telah melakukan pengelolaan kelas dengan baik, tetapi dikarenakan di dalam satu kelas terdapat dua puluhan anak, membuat guru benar-benar harus mengeluarkan tenaga ekstra, 6) hambatan alat berkisah, di dalam (Hildebrandt, Lewis, Kreuger, Naytowhow, \& Tupper, 2016, p. 1432) dikatakan bahwa mendongeng telah dapat dilakukan secara digital untuk peserta didik. Di sini sekolah belum menyediakan alat bantu berkisah seperti audio dan audio visual, alat ini sangat membantu guru dalam melakukan kegiatan berkisah karena akan menarik perhatian anak dan salah satu variasi.

Dalam proses belajar mengajar, pendidik dianjurkan untuk menggunakan metode yang bervariasi untuk menghindari kebosanan, metode cerita/kisah salah satu cara menanamkan kebiasaan baik (Hasmalena, 2017, p. 82). Cerita atau kisah merupakan salah satu metode pendidikan yang baik dan sering kali dilupakan atau diacuhkan oleh mayoritas orang tua atau pendidik pada masa sekarang ini, karena alasan karena sedikitnya waktu yang mereka miliki, atau karena tidak adanya cerita yang cocok (Riyadh, 2011, p. 1). Anak adalah harapan masa depan orang tua bahkan bangsa yang akan membentuk sebuah generasi penerus para orang tua. Maka peningkatan pengetahuan dan keterampilan, pembinaan mental dan moral harus selalu ditingkatkan. Menghadapi era globalisasi yang ditandai dengan berbagai perubahan tata nilai, maka anak harus mendapat pembinaan intensif dan terpadu(Nasiruddin, 2018, p. 325). Orang tua sadar sangat penting menanamkan nilai-nilai pendidikan karakter religius kepada anak sedini mungkin, mengingat banyaknya kasus pelecehan seksual terhadap anak, maka sejak dini anak harus diberikan pendidikan karakter, agar saat dewasa mereka dapat mempertimbangkan baik dan buruknya sesuatu 
sesuai dengan ajaran agama yang dianutnya sebelum mereka melakukan suatu hal, tetapi dengan alasan kesibukan, orang tua sering melupakan pentingnya membacakan sebuah kisah kepada anak, para orang tua berharap lebih kepada sekolah dalam hal tersebut, dikarenakan anak-anak menghabiskan banyak waktu di sekolah.

Nilai religius adalah konsep pokok dalam kehidupan beragama yang bersifat suci sehingga dijadikan pedoman tingkah laku keagamaan masyarakat (Surur, Agus Miftakus, Eka Septiarini, 2018, p. 42). Nilai karakter religius yang ditanamkan melalui pendidikan karakter di sekolah haruslah berbasis kepada Al-Quran dan sunnah sebagai pedoman hidup seluruh umat muslim (Dwi, 2017). Begitu pula dengan pemilihan cerita/kisah yang ingin disampaikan kepada anak haruslah berdasarkan Al-Qur'an dan Hadis yang merupakan pedoman hidup umat Islam, agar tercapainya tujuan pendidikan Islam tertinggi yaitu akhlak mulia. Memberikan keteladanan merupakan salah satu cara mengembangkan karakter anak (K. D., 2010, p. 80),

Menurut (Gunawan, Suyitno, \& Supriyadi, 2018, p. 341) wujud religius hubungan manusia dengan Tuhan diantaranya, beribadah, mengucap salam, berdoa, bersyukur dan mohon ampun. Wujud religius manusia dengan manusia di antaranya meminta perlindungan, berbakti kepada orang tua, keakraban, dan mendoakan orang lain. Selanjutnya, wujud religius manusia dengan alam yaitu memuji keindahan alam, hubungannya dengan diri sendiri yaitu rasa nasionalis dan rasa toleransi antara umat beragama. contoh keteladanan dapat diberikan melalui kisah. Selanjutnya untuk melihat perkembangan karakter religius anak usia dini di TK ABA Sapen Yogyakarta, setelah melakukan evaluasi indikator-indikator dari standart tingkat pencapaian perkembangan (STPPA) nilai agama dan moral pada anak usia 5-6 tahun sebagai berikut:

Mengenal agama yang dianut, para pendidik dapat melihat bagaimana anak mengenal agama yang dianut anak, ketika anak melafalkan dengan benar, lengkap dan mempraktekkan doa sesuai dengan agama yang dianut serta mengingatkan temannya dalam kehidupan sehari-hari. Mengerjakan ibadah, pada indikator mengerjakan ibadah ini akan terlihat ketika anak mampu untuk mengerjakan praktek ibadah sesuai dengan agama yang dianut dengan mandiri, benar, dan tertip serta mampu mengajak orang lain untuk melakukannya dalam kehidupan sehari-hari. Berperilaku Jujur, Penolong, hormat, sportif, indikator berperilaku jujur, penolong, hormat, dan sportif anak terlihat ketika anak dapat mempraktekkan serta mengingatkan perilaku jujur, penolong, dan sportif dalam kehidupan sehari-hari.

Menghormati (toleransi) agama orang lain, dengan adanya toleransi maka seseorang yang sangat peduli dengan perasaan orang lain dan tidak pernah merendahkan siapapun (Tillman, 2004, p. 141), ini dapat dilihat dari kegiatan anak sehari-hari di TK ABA Sapen Yogyakarta yang mempunyai latar belakang keluarga yang berbeda-beda, tetapi anak-anak tidak saling mengejek, yang terlihat anak tidak memilih-milih teman dan saling membantu. Toleransi beragama yang akan ditunjukkan oleh anak adalah anak dapat menunjukkan sikap menghormati agama temannya yang dalam kehidupan sehari-hari dan mengingatkan temannya dalam toleransi beragama. Hal ini dapat terjadi dikarenakan kisah sebagai metode pembelajaran yang cukup efektif untuk anak usia dini, terutama untuk mengemangkan pendidikan karakter. Alasannya adalah kisah dapat mengambil hikmah tanpa rasa menggurui anak (Aziz, 2018, p. 51.).

Suatu nilai yang diwujudkan dalam perilaku merupakan karakter (Arif, 2014, p. 97). Pada masa anak-anak akan lebih mudah dalam menerima nila-nilai pembelajaran, dibandingkan dengan menyeramahi anak atau menasehatinya secara langsung tanpa ada gambaran kisah yang menarik bagi anak, hal ini disebabkan karena nilai-nilai tersebut diketahui anak dengan rasa ingin tahu yang tinggi, masuk ke dalam diri anak tanpa adanya paksaan dari luar. Pendidikan seharusnya mampu menghadirkan generasi yang bermoral dan berkarakter kuat karena manusia sesungguhnya dapat dididik (Inawati, 2017, p. 54). Sehingga membacakan kisah-kisah Al-Qur'an pada anak merupakan cara yang sangat 
ampuh untuk mengembangkan karakter anak yang religius, kisah-kisah ini akan tertanam dalam diri anak dan secara tidak langsung akan berpengaruh pada kepribadian anak. Menurut (Zubaedi, 2012, p. 145) mengatakan bahwa keluarga dan lingkungan sekitar merupakan wahana pertama dalam perkembangan karakter anak. Melalui kisah-kisah yang didengarkan oleh anak, terjadilah perubahan pada tingkah laku dan perkataan anak yang sesuai dengan nilai-nilai luhur yang diketahui anak melalui kisah itu.

Kepada para pendidik penting untuk diingat bahwa sebelum menggunakan metode kisah Qur'ani, guru harus memahami kapan metode kisah digunakan dan nilai-nilai yang terkandung di dalamnya serta memahami dengan benar cara penyampaian kepada anak, seperti yang diungkapkan oleh (Jalaludin, 2012, p. 66) bahwasanya guru harus jeli melihat materi yang akan diajarkan pada peserta didik. Menurut (M. A., 2006, p. 16) faktor penghambat dan pendorong pembentukan karakter seseorang dipengaruhi oleh faktor internal dan faktor eksternal. Dalam menerapkan metode kisah Qur'ani guru menemui kendala yang dirasakan, adapun yang termasuk ke dalam faktor internal adalah menyangkut kemampuan seorang guru dalam menguasai teknik, alur, dan strategi yang digunakan ketika kegiatan berlangsung guru menciptakan hubungan yang baik dan akrab sehingga tidak ada kesan bahwa guru adalah figur yang menakutkan bagi anak (Ananda, 2017, p. 23). Dikarenakan tidak semua guru mampu menguasai teknik berkisah dengan baik, sehingga pelatihan yang diberikan oleh pihak sekolah perlu dilakukan secara terus-menerus bukan hanya sekali, ini penting untuk mengasah kualitas guru dalam bercerita/berkisah. Adapun faktor eksternal lebih kepada kurangnya komunikasi pihak sekolah dengan wali murid mengenai pengembangan nilai-nilai karakter religius anak yang dilakukan guru di sekolah agar orang tua di rumah melakukan hal yang sejalan dengan yang dilakukan disekolah.

\section{SIMPULAN}

Proses penerapan metode kisah Qur'ani di TK ABA Sapen Yogyakarta, guru menggunakan beberapa tahapan, tahapan tersebut antara lain: tahap perencanaan, tahap penerapan, dan tahap evaluasi. Guru menggunakan media yang beragam pada pelaksaan metode kisah Qur'ani. Pemilihan kisah berdasarkan banyaknya kandungan nilai-nilai agama dan moral yang terdapat dalam Al-Qur'an dan menyesuaikan kisah dengan tahapan perkembangan anak. Implikasi dari penerapan metode kisah Qur'ani di TK ABA Sapen Yogyakarta dapat dilihat melalui indikator perkembangan nilai agama dan moral anak yang sudah berkembang sesuai tahapan usia anak, indikator tersebut antara lain mengenal agama yang dianut, mengerjakan ibadah, berperilaku Jujur, Penolong, Hormat, Sportif, dsb, menjaga kebersihan diri dan lingkungan, mengetahui hari besar agama, menghormati (toleransi) terhadap agama lain.

\section{UCAPAN TERIMAKASIH}

Ucapan terimakasih kepada seluruh pihak yang telah membantu penulis dalam menyelesaikan artikel jurnal ini, terkhusus kepada kedua orang tua yaitu Bapak Hasbullah dan Ibu Siti Hafsah.

\section{DAFTAR PUSTAKA}

Affani, S., Pamekasan, S., Raya, J., \& Km, P. (2017). Rekonstruksi Kisah Nabi Musa Dalam AlQuran: Studi Perbandingan Dengan Perjanjian Lama. Jurnal Al-Ihkam, 12(1). Https:/ Doi.Org/10.19105/Al-Ihkam.V12i1.1259

Ananda, R. (2017). Implementasi Nilai-Nilai Moral dan Agama Pada Anak Usia Dini. Jurnal Obsesi: Jurnal Pendidikan Anak Usia Dini, 1(1), 19-31. Https://Doi.Org/10.31004/Obsesi.V1i1.28

Arif, M. (2014). Model Pembelajaran Sejarah Dengan Mengintegrasikan Nilai Dan Karakter 
DOI: 10.31004/obsesi.v5i1.523

Religius Melalui Teknik Klarifikasi Nilai. Tarbiya, 1(1). Https://Doi.Org/10.1590/S1809-98232013000400007

Aziz, S. Dan H. (2018). Qashashul Qur'an Bekal Utama Juru Kisah. Yogyakarta: Akademi Berkisah.

Bagir, H. (2019). Memulihkan Sekolah Memulihkan Manusia: Meluruskan Kembali Falsafah Pendidikan Kita. Bandung: Mizan.

Britton, L. (1992). Montessory Play And Learn: A Parents Guide To Perposeful Play From Two To Six. Crown Publishing Grup.

Cahya, Fajar Septian, Bahri, S. (2016). Nilai-Nilai Karakter Dalam Kitab Al-Akhlaq Lil Banin $\begin{array}{llll}\text { Karya Syekh Umar Badja. } & \text { 72(1), }\end{array}$ Https://Doi.Org/Doi.Org/10.21009/JSQ.012.1.04

Creswell, J. W. (2010). Reaserch Design Pendekatan Kualitatif, Kuantitatif, Dan Mixed. Yogyakarta: Pustaka Pelajar.

Creswell, J. W. (2015). Penelitian Kualitatif \& Desain Riset, Terj. Ahmad Lintang Lazuardi. Yogyakarta: Pustaka Pelajar.

Dalimunthe, S. S. (2016). Metode Kisah Dalam Perspektif Al-Qur'an. Jurnal Tarbiyah, 23(2).

Dwi, S. S. (2017). Implementasi Nilai Religius Dalam Pendidikan Karakter Berbasissinnah Rasulullah (Studi Kasus Di STAN -Najah Takengon, Aceh Tengoh). HIJRI (Jurnal Manajemen Pendidikan Islam), 6(2), 1-13.

Eriani, E. (2019). Story Telling Using Madihin: Learning Methods For Early Childhood Listening Skills. Jurnal Obsesi: Jurnal Pendidikan Anak Usia Dini, 3(2), 303-310. Https://Doi.Org/10.31004/Obsesi.V3i2.172

Gunawan, R., Suyitno, \& Supriyadi, S. (2018). Nilai Pendidikan Karakter Religius Dan Cinta Tanah Air Novel Rantau 1 Muara Karya Ahmad Fuadi. AKADEMIKA: Jurnal Pemikiran Islam, 23(2), 331. Https:/ / Doi.Org/10.32332/ Akademika.V23i2.1238

Harlock, E. B. (2009). Psikologi Perkembangan: Suatu Pendekatan Sepanjang Rentang Kehidupan. Jakarta: Erlangga.

Hasan, S. H. (2010). Bahan Pelatihan Penguatan Metodologi Pembelajaran Berdasarkan Nilai-Nilai Budaya Untuk Membentuk Daya Saing Dan Karakter Bangsa. Jakarta.

Hasmalena, M. R. (2017). Jurnal Obsesi : Jurnal Pendidikan Anak Usia Dini Impelementasi Cerita Rakyat Melalui Mata Kuliah Pendidikan Seni Tari. Jurnal Obsesi: Jurnal Pendidikan Anak Usia Dini, 1(2), 81-85. Https:/ / Doi.Org/10.31004/Obsesi.V1i2.18

Hildebrandt, K., Lewis, P., Kreuger, C., Naytowhow, J., \& Tupper, J. (2016). Digital Storytelling For Historical Understanding: Treaty Education For Reconciliation. 15(1), $17-$ 26. Https:/ / Doi.Org/10.4119/UNIBI/Jsse-V15-I1-1432

Inawati, A. (2017). Strategi Pengembangan Moral Dan Nilai Agama Untuk Anak Usia Dini Asti Inawati. Al-Athfal Jurnal Pendidikan Anak, 3(1), 51-64.

Jalaludin. (2012). Psikologi Agama. Jakarta: Raja Grafindo Persada.

K. D., A. (2010). Pendidikan Karakter Strategi Mendidik Anak Di Zaman Global. Jakarta: Grasindo.

Khadijah. (2017). Perkembangan Kognitif Anak Usia Dini. Medan: Perdana Publishing.

Kurniasih, I. (2010). Mendidik SQ Anak. Jakarta: Pustaka Marwa.

M. A., M. (2006). Membentuk Karakter Cara Islam. Jakarta: Al-I'tishom Cahaya Umat.

Manney, P. J. (2008). Empathy In The Time Of Technology: How Storytelling Is The Key To Empathy. Journal Of Evolution And Technology, 19(1).

Masdalipah. (2017). Implementasi Model Tematik Dalam Pembelajaran Agama Islam Pada Pendidikan Anak Usia Dini Di Raudhatul Athfal Al-Jihad. Ta'dibuna, 6(1), 2.

Mucharomah, M. (2017). Kisah Sebagai Metode Pendidikan Akhlak Dalam Perspektif AlQur`An. Edukasia Islamika Jurnal Pendidikan Islam, 2(1), 146-171. Https://Doi.Org/Https:/ /Doi.Org/10.28918/Jei.V2i1.1666

Muslich, M. (2011). Pendidikan Karakter: Menjawab Tantangan Krisis Multidimensional. Jakarta: Bumi Aksara. 
Nasiruddin. (2018). Pembentukan Karakter Anak Melalui Keteladanan Orang Tua Nasiruddin. Jurnal Kependidikan, 6(2), 323-333. Https:/ Doi.Org/Https:/ Doi.Org/10.24090/Jk.V6i2.1933

Nur'aini, A. (2016). Peran Orang Tua Dalam Pegembangan Literasi Dini Anak Kelompok B Di Gugus 7 Mangunan Dlingo Bantul. Jurnal Pendidikan Anak Usia Dini, 5(3).

Pura, D. N. (2019). Perkembangan Motorik Halus Anak Usia Dini Melalui Kolase Media Serutan Pensil. Jurnal Ilmiah Potensia, 4(2), 131-140. Https://Doi.Org/Https:/ / Doi.Org/10.33369/Jip.4.2.131-140

Ridla, M. J. (2002). Tiga Aliran Utama Teori Pendidikan Islam (Perspektif Sosiologis-Filosofis). Yogyakarta: Tiara Wacana.

Riyadh, S. (2011). Melatih Otak Dan Komunikasi Anak: Meningkatkan Kecerdasan Dan Kemampuan Anak Lewat Cerita. Jakarta: Akbar Media.

Rohinah. (2018). Experiential Learning Dalam Pembelajaran Agama Anak Usia Dini Berbasis Sekolah Alam Di TKIT Nurul Islam Yogyakarta. Islamic Early Childhood Education, 3(1).

Rokim, S. (2015). Ibadah-Ibadah Ilahi Dan Manfaatnya Dalam Pendidikan Jasmani. Edukasi Islami Jurnal Pendidikan Islam, 1(4).

Sit, M. (2016). Mengembangkan Sikap Cinta Allah Dan Rasul Melalui Metode Kisah Pada Anak Usia Dini. Raudhah, 4(1).

Sudjana, N. (2017). Penilaian Proses Hasil Belajar Mengajar. Bandung: Remaja Rosda Karya.

Surur, Agus Miftakus, Eka Septiarini, A. Y. T. (2018). Upaya Menanamkan Nilai Religius Siswa Di Man Kediri 1 Kota Kediri Melalui Ekstrakurikuler Keagaman Tahfidz AlQur'an. Jurnal Pendidikan Agama Islam, XV(1). Https://Doi.Org/10.14421/Jpai.2018.151-03

Suyadi. (2018). Kisah (Storytelling) Pada Pembelajaran Anak Usia Dini Dalam Kajian Neurosains Pendidikan Islam. Jurnal Ilmiah Islam Futura, 18(1), 52-74.

Suyanta, S. (2013). Membangun Pendidikan Karakter Dalam Masyarakat. Jurnal Ilmiah Islam Futura, 13(1).

Syahraini, T. (2014). Metode Komunikatif Pendidikan Agama Islam. Yogyakarta: Graha Ilmu.

Tanto, O. D., \& Supena, A. (2019). Jurnal Obsesi : Jurnal Pendidikan Anak Usia Dini Penanaman Karakter Anak Usia Dini Dalam Kesenian Tradisional Tatah Sungging. 3(2), 337-345. Https://Doi.Org/10.31004/Obsesi.V3i2.192

Tillman, D. (2004). Living Value Activities For Children Ages. Jakarta: Gramedia Widiasarana.

Trimuliana, I., Dhieni, N., \& Hapidin, H. (2019). Perilaku Religius Anak Usia 5-6 Tahun Pada PAUD Model Karakter. Jurnal Obsesi: Jurnal Pendidikan Anak Usia Dini, 3(2), 570. Https:/ /Doi.Org/10.31004/Obsesi.V3i2.251

Umayah. (2016). Menanamkan Moral Dan Nilai-Nilai Agama Pada Anak Usia Dini Melalui Cerita. Jurnal Pendidikan Guru Raudlatul Athfal, 1(1), 96-105.

Yasyakur, M. (2017). Model Pembelajaran Berkarakter Dalam Perspektif Al-Quran (Pada Sekolah Islam Terpadu Full Day School) Moch. Jurnal Edukasi Islami Jurnal Pendidikan Islam, 06(11). Https:/ / Doi.Org/Http://Dx.Doi.Org/10.30868/Ei.V6i11.96

Zein, A. (2018). Nilai-Nilai Pendidikan Dalam Al-Qur'an (Kajian Tafsir Kisah Nabi Musa Dalam Surah Al-Qasas Ayat 1-13). Edu Eriligia, 2(2).

Zubaedi. (2012). Desain Pendidikan Karakter Konsepsi Dan Aplikasinya Dalam Dunia Pendidikan. Jakarta: Kencana.

Zurqoni. (2018). Penguatan Nilai-Nilai Agama Dan Moral Anak Usia Dini. Syamil, 6(1), 6586. 